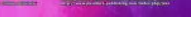

\title{
Pengaruh Zikir Terhadap Penurunan Kecemasan Terhadap Dampak Pandemi Covid-19 Komunitas Tarekat Syattariyah Di Kecamatan Medan Denai
}

\author{
Nurfadillah Rizki Damanik ${ }^{1}$, Safria Andy ${ }^{2}$, Sholahuddin Ashani ${ }^{3}$. \\ 1,2,3 Universitas Islam Negeri Sumatera Utara
}

Corresponding Author: @ nurfadillahrizkidamanik@gmail.com

\begin{tabular}{|c|c|}
\hline & ABSTRACT \\
\hline & $\begin{array}{l}\text { Penelitian ini mengkaji tentang pengaruh zikir terhadap penurunan } \\
\text { kecemasan di masa pandemi Covid-19. Berbagai bentuk kecemasan yang } \\
\text { terjadi pada manusia yang terdampak Covid-19 sehingga memberi efek } \\
\text { cemas, gelisah, khawatir pada diri mereka. Tujuan yang hendak dicapai } \\
\text { dari penelitian ini adalah untuk mengetahui dan memahami serta } \\
\text { merasakan ketenangan dalam hati dari terapi zikir. Zikir merupakan } \\
\text { kalimat-kalimat pujian kepada Allah Swt dan berupa jalan untuk lebih } \\
\text { dekat dengan Allah Swt. Zikir dapat membebaskan seseorang dari rasa } \\
\text { cemas dan trauma di masa pandemi Covid-19 yang terjadi pada tahun } \\
\text { 2020. Jenis penelitian ini adalah kualitatif dengan pendekatan lapangan } \\
\text { disertai dengan pendekatan literatur (buku-buku, artikel, jurnal, skripsi } \\
\text { dan tesis). Jenis data yang digunakan dalam penelitian ini adalah data } \\
\text { primer dan data skunder. Berdasarkan analisis temuan penelitian ini } \\
\text { dapat disimpulkan bahwa zikir dapat membantu menurunkan tingkat } \\
\text { kecemasan di masa pandemi Covid-19. Fakta dilapangan menyebutkan } \\
\text { bahwasannya masyarakat terdampak Covid-19 yang berzikir merasa } \\
\text { hatinya menjadi lebih tenang dan lebih ikhlas dalam menghadapi } \\
\text { musibah. Selalu berbaik sangka kepada Allah Swt atas ujian yang } \\
\text { diberikan melalui Covid-19 ini. Masyarakat yang berzikir semakin } \\
\text { bertawakal dan beriman kepada Allah Swt, sehingga membuat mereka } \\
\text { tidak merasa takut dan cemas menghadapi pandemi Covid-19. }\end{array}$ \\
\hline $\begin{array}{l}\text { Kata Kunci } \\
\text { Keywords }\end{array}$ & Zikir, Kecemasan, Covid-19. \\
\hline How to cite & (2021). Jurnal Ability, 2(4). \\
\hline
\end{tabular}

\section{PENDAHULUAN}

Saat ini dunia benar-benar digemparkan oleh suatu wabah atau virus yang bernama corona. Coronavirus atau yang disebut juga dengan virus corona merupakan keluarga besar virus yang mengakibatkan terjadinya infeksi saluran pernafasan atas ringan hingga sedang seperti penyakit flu. Beberapa jenis virus corona juga bisa menimbulkan penyakit yang lebih serius.

Setiap manusia memiliki kehidupan yang begitu beragam jika dipandang dari berbagai aspek, ditambah era globalisasi yang berperan penting dalam perubahan pada setiap individu dari berbagai level. Pada era masa kini 
Ability : Journal of Education and Social Analysis

Volume 2, Issue 4, Oktober 2021

Page : 63-76

merupakan era kegelisahan, permasalahan kehidupan dapat terlihat dan mampu dirasakan di manapun individu berada. Hal ini dikarenakan telah timbul kebutuhan yang meningkat namun semakin minim tingkat kedamaian yang terjadi. Dengan kondisi tersebut maka tidak heran bila perasaan tidak tenang merupakan salah satu tolak ukur seseorang menjadi stress atau cemas (Shihab, 2008).

Rasa pesimis dan takut dalam menjalani hidup melanda kebanyakan masyarakat, dimana kehidupan yang semakin rumit dan tidak terarah menjadi salah satu hal yang bisa membuat masyarakat mengalami kecemasan. Apalagi masyarakat yang tak memiliki pegangan iman sama sekali dan hanya mengandalkan materi belaka, mereka akan kehilangan arti dan tujuan dalam hidup (Hayat, 2007).

Kecemasan adalah manifestasi dari berbagai proses emosi yang sedang bercampur baur, yang terjadi ketika seseorang sedang mengalami tekanan perasaan (frustasi) dan pertentangan batin (konflik). Kecemasan itu mempunyai segi yang disadari seperti rasa takut, terkejut, tidak berdaya, rasa berdosa atau bersalah, terancam dan sebagainya. Kecemasan merupakan perasaan subyektif yang mempunyai reaksi terhadap pengalaman yang tidak menyenangkan. Semua orang pasti pernah mengalami kecemasan dan tidak dapat segera mengatasinya atau ketidakmampuan menghilangkan perasaan cemas, ketika dalam keadaan seperti itu pasti seseorang mendambakan ketenangan batin.

Allah Swt telah menjelaskan bahwa pada dasarnya manusia itu memang telah diciptakan dengan membawa emosi cemas atau dengan kata lain manusia diciptakan oleh Allah Swt dengan penuh keluh kesah. Hal ini menunjukkan bahwa manusia itu memang memiliki potensi kecemasan dalam hidupnya. Sebagaimana firman Allah dalam QS. Al-Ma'arij 70 : 19-20 dan QS. Al-Baqarah $2: 155$.

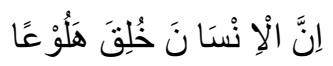

Artinya : Sungguh Manusia diciptakan bersifat suka mengeluh. (Qs. Al-Ma'arij : 19)

Artinya : Apabila ia ditimpah kesusahan ia berkeluh kesah. (Qs. Al-Ma'arij : 20)

Zikir merupakan suatu jalan keagamaan untuk memberi ketenangan dan ketentraman bagi masyarakat yang terdampak pandemi. Saat pandemi, sebagian besar masyarakat mencemaskan hidupnya, mulai dari perekonomian, pendidikian, serta keagamaannya. Bagaimana tidak, di era pandemi masyarakat diharuskan untuk tetap di rumah dan tidak boleh bekerja, sementara kebutuhan hidup pokok harus tetap terpenuhi setriap harinya. Para 
Ability : Journal of Education and Social Analysis

Volume 2, Issue 4, Oktober 2021

Page : 63-76

pelajar yang diharuskan melakukan pelajaran dalam jaringan, hal tersebut justru semakin menyulitkan para orang tua, dan masjid masjid yang ditutup karena pandemi menghambat kegiatan-kegiatan keagamaan yang biasa dilakukan serta membuat kurangnya kemakmuran masjid karena para jamaah memilih ibadah di rumah. Maka, munculah kegelisahan dan kecemasan ditengah masyarakat sehingga mereka menjadi panik bahkan lupa akan Tuhan. Didalam penelitian ini, peneliti akan meneliti sebuah lokasi yang terdapat Tarekat yang mampu untuk memberikan terapi zikir untuk memberikan efek ketenangan jiwa di masa pandemi. Zikir juga bisa menjadi penghubung dan penolong antara hamba dan Tuhan nya. Berkaitan dengan hal tersebut Allah SWT berfirman dalam Alquran :

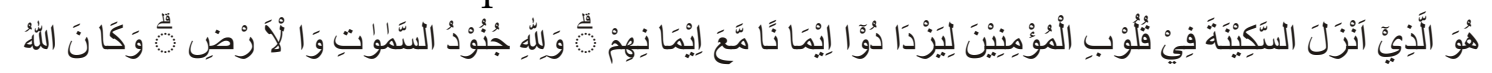

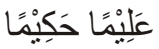

Artinya : Dialah yang telah menurunkan ketenangan kedalam hati orang-orang mukmin untuk menambah keimanan atas keimanan mereka (yang telah ada). Dan milik Allah lah bala tentara langit dan bumi, dan Allah Maha Mengetahui, Maha Bijaksana. (QS. Al-Fath:4)

Zikir membantu individu membentuk persepsi yang lain selain ketakutan, yaitu keyakinan bahwa semua konflik akan dapat dihadapi dengan baik melalui bantuan Allah Swt. Saat seseorang membiasakan berzikir, maka ia akan merasa dirinya dekat dengan Allah Swt, berada dalam penjagaan dan lindungan-Nya, yang kemudian akan membangkitkan percaya diri, kekuatan, perasaan aman, tentram dan bahagia. Kalimat zikir yang digunakan adalah kalimat istighfar Asatgfirullahal'azim (Saya mohon ampun keapada Allah yang Maha Agung). Kalimat zikir tersebut diucapkan berulang-ulang dengan tujuan sebagai proses pembelajaran dan melatih membangun daya juang dan kesungguhan demi meraih ridha, cinta, dan perjumpaan dengan Allah Swt (Najati, 2005).

Di masa pandemi, upaya penanganan kecemasan perlu menggunakan pendekatan yang bersifat holistik (menyeluruh). Zikir memberi dampak positif pada aspek kognitif, afektif, dan spiritual. Pada aspek kognitif, bacaan zikir memberikan pemahaman yang positif. Pada aspek afektif, pemahaman positif yang timbul karena zikir menumbuhkan rasa optimisme bahwa setiap permasalahan dapat dihadapi. Selain itu, zikir disebut sebagai teknik relaksasi Islam sehingga membuat perasaan yang tegang menjadi tenang. Aspek spiritual zikir menumbuhkan kesadaran untuk berpasrah kepada Allah Swt (Anward, 2002). Sebagaimana yang diungkapkan Jalaluddin bahwa penyerahan diri kepada Allah Swt memberikan ketenangan batin atau jiwa (Jalaluddin, 2009). 
Ability : Journal of Education and Social Analysis

Volume 2, Issue 4, Oktober 2021

Page : 63-76

\section{METODE PENELITIAN}

Jenis penelitian ini termasuk penelitian lapangan (Field Research) dengan pendekatan kualitatif. Alasaan menggunakan pendekatan kualitatif adalah karena penelitian kualitatif dapat menjelaskan suatu fenomena dengan sedalam-dalamnya dengan cara pengumpulan data. Terkait hal tersebut maka penelitian kualitatif sangat mendukug untuk situasi saat ini dan untuk judul skripsi saya. Dengan penelitian kulitatif, peneliti dapat dengan mudah untuk menggali informasi yang lebih dalam terkait suatu topik penelitian yang nantinya informasi yang didapatkan dapat digunakan untuk menentukan tujuan penelitian. Informan dalam penelitian adalah orang atau pelaku yang benar-benar tahu dan menguasai masalah, serta terlibat langsung dalam masalah penelitian. Dalam penelitian ini, sumber data primer adalah langsung dari pengikut tarekat syattariyah yaitu narasumber yang menguasai permasalahan dalam penelitian ini yaitu Syeikh Tuanku Hasan Basry selaku Ulama Syattariyah Kecamatan Medan Denai. Data sekunder peneliti mengambil dari pernyataan murid/jamaah diluar Tarekat, tokoh agama disekitar musholla yang bukan bagian dari komunitas Tarekat, serta bukubuku, jurnal dan skripsi yang berhubungan dengan penelitian ini.

\section{HASIL DAN PEMBAHASAN}

\section{Zikir dan Kecemasan}

Zikir berasal dari bahasa Arab, yaitu asal kata dari dzakara, yadzkuru, dzikran yang mempunyai arti sebut dan ingat. Zikir secara bahasa bermakna mengingat atau menyebut. Dalam ajaran Islam khususnya Tasawuf, Zikir itu diartikan sebagai suatu usaha untuk mengingat Allah dan melupakan selain Allah. Zikir merupakan sesuatu yang sangat utama dalam ajaran islam termasuk dalam bertasawuf. Zikir harus dilakukan sebanyak-banyaknya tanpa pilih waktu. Zikir berfungsi untuk memelihara Allah dalam hati dan lisan, sehingga tidak lupa dengan-Nya. Dengan demikian Allah senantiasa terasa hadir dalam hati sepenuhnya, dan aplikasinya akan lahirlah amal shaleh dalam diri dan khasiatnya adalah terbentuknya hijab dari Allah Swt (Miswar, 2015).

Zikir dapat dilakukan dengan cara lisan dan hati, dan lafal zikir tersebut bisa berupa tasbih, tahmid, tahlil, takbir, dan ta'zhim. Hal ini sejalan dengan yang dikatan oleh Ar-Raghib al-Iisfahani, bahwa zikir ialah apa yang dilakukan oleh hati dan lisan berupa tasbih atau mensucikan Allah Ta'ala, memuji dan menyanjung-Nya. Menyebutkan sifat-sifat kebesaran dan keagungan-Nya, serta sifat-sifat keindahan dan kesempurnaan yang dimiliki-Nya.

Zikir dalam arti menyebut nama Allah, biasanya diamalkan secara rutin dan cukup umum dikenal dengan istilah wirid. Wirid adalah untaian kata-kata 
Ability : Journal of Education and Social Analysis

Volume 2, Issue 4, Oktober 2021

Page : $63-76$

zikir yang ma'tsurat (ada contoh dan tuntunan dari Rasulullah). Zikir dalam konteks ini termasuk ibadah mahdhah, yaitu ibadah yang langsung kepada Allah, seperti zikir-zikir ketika shalat, setelah shalat, ketika haji dan umrah, dan lain-lain (Mahfani, 2006).

Kecemasan merupakan salah satu masalah psikologis yang banyak dijumpai dan merupakan suatu yang tidak asing dalam kehidupan bermasyarakat, karena kecemasan merupakan pengalaman universal yang dapat dialami oleh siapa saja, kapan saja, dan dimana saja. Freud mendefenisikan kecemasan adalah suatu keadaan tegang yang memotivasi kita untuk berbuat sesuatu. Fungsinya adalah untuk memperingatkan seseorang akan bahaya yang mengancam dirinya, yakni sinyal ego yang akan terus meningkat bila ancaman ego itu tidak segera di ambil dan diperbaiki. Apabila tidak dapat mengendalikan kecemasan melalui cara-cara yang rasional dan langsung, maka ego akan mengandalkan cara-cara yang tidak realistis, yakni tingkah laku yang berorientasi pada pertahanan ego, karena ego merupakan komponen dari psikologis.

Kecemasan mempunyai gejala-gejala gangguan fungsi dari organ-organ tubuh yang disarafi oleh sistem syaraf otonom misalnya: pernafasan, peredaran darah, sistem pencernaan dan lain sebagainya. Gejala-gejala kecemasan menurut Dadang Hawari (1978) ditandai oleh beberapa faktor yaitu :

1. Cemas, Takut, dan Khawatir

2. Firasat Buruk

3. Takut akan fikirannya sendiri

4. Mudah Tersinggung

5. Tegang, tak bisa istirahat dengan tenang

6. Gelisah, mudah terkejut

7. Gangguan tidur dengan mimpi-mimpi yang menegangkan

8. Gangguan konsentrasi dan daya ingat

9. Jantung berdebar-debar, dada sesak, nafas sesak

10. Gangguan pencernaan

11. Nyeri otot, pegal linu, kau, perasaan seperti ditusuk-tusuk, berkeringat, badan panas atau dingin

12. Mulut kering, sukar menelan seolah olah ada benda yang menyumbat kerongkongan

13. Gangguan seksual (libido meninggi) 
Ability : Journal of Education and Social Analysis

Volume 2, Issue 4, Oktober 2021

Page : 63-76

Disamping gejala-gejala kecemasan di atas, Menurut Sutadi (2010) berikut ini merupakan fungsi yang dapat dipengaruhi oleh gangguan kecemasan yaitu

1. Suasana Hati: Mudah marah, dan perasaan sangat tegang.

2. Pikiran : Khawatir, sukar berkonsentrasi, pikiran kosong, suka membesar-besarkan ancaman, memandang diri sangat sensitive, merasa tidak berdaya.

3. Motivasi: Menghindari situasi, ketergantungan tinggi, ingin melarikan diri.

4. Perilaku : Gelisah, gugup, kewaspadaan yang berlebihan.

\section{Kecemasan di Masa Pandemi Covid-19}

a. Kecemasan Perekonomian

Perekonomian adalah kecemasan yang paling dirasakan oleh masyarakat, mereka cemas akan pemenuhan kebutuhan sehari-hari di masa pandemi. Pada kenyataan yang kita lihat, di masa pandemi kini banyak para pekerja yang dibatasi dalam bekerja (work from home) bahkan di PHK (Pemutusan Hubungan Kerja). Tidak hanya itu, di masa pandemi seperti ini bahan baku yang menjadi kebutuhan pokok semakin tidak terkendali harganya. Belum lagi kebijakan pemerintah yang melakukan Pemberlakuan Pembatasan Kegiatan Masyarakat (PPKM) yang membuat masyarakat semakin terjepit oleh keadaan, mereka dilarang untuk bekerja, berjualan, dan beraktivitas seperti biasanya padahal kehidupan harus terus berjalan dan kebutuhan hidup harus tetap terpenuhi disetiap harinya. Pemerintah juga merasakan kerugian akibat covid-19 ini, kerugian demi kerugian terus dirasakan masyarakat Indonesia sehingga mereka merasa tertekan dan merasa kacau hati dan pikirannya (Rahmadia, 2020).

b. Kecemasan Pendidikan

Pendidikan adalah hal yang sangat penting bagi masa depan seseorang dalam menjalai kehidupan. Sudah hampir 2 tahun lamanya pemerintah menerapkan sistem daring (dalam jaringan) dalam melaukan proses belajar mengajar. Hal tersebut menjadi kecemasan yang luar biasa bagi masyarakat. Kecemasan yang terjadi pada siswa yang belajar daring adalah kurangnya pemahaman akan pembelajaran yang diberikan guru melalui video atau naskah teks, belum lagi tekanan-tekanan yang diterima dari orang tua ketika belajar dirumah, tekanan tugas yang tidak ada habisnya menjadi penyebab siswa stress dan menjadi cemas.

Kemudian kecemasan yang terjadi pada orang tua adalah kekhawatiran tidak mampu memfasilitasi anaknya dalam pembelajaran 
Ability : Journal of Education and Social Analysis

Volume 2, Issue 4, Oktober 2021

Page : 63-76

online (daring) tersebut, dimana para orang tua tidak mampu memberikan hp atau laptop untuk anaknya belajar, belum lagi kuota internet yang harus disediakan setiap pembelajaran. Orang tua yang bekerja tidak dapat mengawasi anaknya dengan baik sehingga mereka khawatir anaknya justru melakukan hal-hal yang tidak benar dari fasilitas hp atau laptop yang mereka berikan, belum lagi kegelisahan orang tua untuk merangkap menjadi guru bagi anaknya, mereka juga takut karena kurang efektifnya pembelajaran anaknya tidak dapat menambah wawasan padahal uang pendidikan terus menerus dibayar.

Kecemasan akan pendidikan yang terjadi di masa pandemi tidak hanya dirasakan oleh siswa dan orang tua saja, namun guru justru lebih merasakan tekanan akibat pembelajaran daring tersebut. Guru dituntuk harus lebih kreatif dalam memberikan pembelajaran baik dalam bentuk video maupun naskah teks agar siswa tidak bosan dan dapat dengan mudah memahami pembelajaran yang diberikan. Kemudian guru juga dituntut harus mampu menguasai teknologi dan dapat memfasilitasi dirinya sendiri di masa pembelajaran daring ini, guru juga wajib terus aktif dalam pembelajaran online melalui aplikasi yang telah disepakati, dan guru juga dituntut untuk mencerdaskan anak bangsa melalui jarak jauh di masa polemik pandemi saat ini.

c. Kecemasan Terhadap Penularan Virus Covid-19

Kecemasan akan bahaya covid-19 akan memporak-porandakan masyarakat karena berita-berita hoax yang tersebar di berbagai media. Masyarakat menjadi semakin takut akan virus covid-19 melihat sudah banyaknya korban jiwa yang meninggal akibat terpapar virus ini. Masyarakat akan paranoid sehingga mengasingkan diri dari interaksi sosial yang biasa dilakukan. Kecemasan ini akan terus meningkat jika masyarakat terus menerus disuguhi dengan berita mengerihkan. Dalam hal ini, diperlukannya edukasi mengenai pandemi agar masyarakat lebih bijak dalam menghadapi pandemi dan tidak merasa cemas yang kemudian menjadi stress (Aulia, 2018).

\section{Hubungan Zikir dan Kecemasan}

Sejarah agama Islam sudah lama menawarkan dan membekali pemeluknya dalam mengatasi atau menanggulangi penyakit hati atau jiwa seperti kecemasan, gelisah, stress, dan phobia. Berbagai dimensi agama, seperti beriman dan berzikir disertai dengan berdoa kepada Allah Swt, digunakan para psikoterafis yang menggunakan pendekatan agama dalam rangka 
Ability : Journal of Education and Social Analysis

Volume 2, Issue 4, Oktober 2021

Page : 63-76

meningkatkan kemampuan seseorang atau individu dalam mengatasi kecemasan dan akan menentramkan hati.

Adanya indikasi keterkaitan antara zikir dan kecemasan dapat dilihat dari seseorang yang sudah terbiasa berzikir akan menjadi lebih tenang, selalu mengamalkan ibadah zikir disetiap kesempatan, mereka tidak membiarkan waktu luang mereka berlalu begitu saja. Secara psikologis, efek dari perbuatan mengingat Allah akan memberi perkembangan penghayatan akan kehadiran Allah Swt. Dari penghayatan tersebut, bahwa akan timbul kesadaran bahwa ia tidak merasa hidup sendiri di dunia ini, karena ada zat yang Maha Mendengar keluh kesahnya yang mungkin tidak dapat diungkapkan kepada siapapun sehingga individu tidak merasa cemas lagi dalam menjalani setiap kehidupan yang dilalui.

Selain itu, pelaksanaan zikir yang dilakukan dengan sikap rendah hati dan suara yang lemah lembut akan membawa dampak relaksasi dan ketenangan bagi mereka yang melakukannya. Zikir jika dilakukan dengan baik dapat dijadikan sebagai terapi kecemasan. Penyebutan lafaz-lafaz zikir akan dapat menenangkan dan memberikan efek rileks pikiran dan hati sehingga pikiran menjadi tenang dan hati menjadi tenteram. Secara sederhana, bila seseorang ingin mendapatkan rasa tenang dan tenteram serta bebas dari kecemasan, maka dekatilah Dia yang Maha Tenang dan Maha Tenteram yaitu Allah Swt.

Penyebutan dan ingatan pada Allah Swt (zikir) secara terus menerus dengan penuh kehidmatan akan membiasakan hati sanubari senantiasa dekat dengan Sang Khalik. Efeknya akan berkembang kecintaan yang mendalam kepada Allah dan akan semakin baik hubungan antara hamba dan Tuhannya, sehingga seseorang bisa menerima dan mensyukuri setiap apa yabg telah ditentukan oleh Allah Swt kepadanya.

Orang-orang yang dekat dengan Allah akan selalu dapat menikmati segala hal yang dialami, baik itu kesulitan maupun kebahagiaan. Karena itu ia tidak akan putus asa dan tidak mudah menyerah ketika menghadapi kesulitan atau kegagalan. Baginya kesulitan dan kegagalan adalah sebuah proses pendewasaan diri yang diajarakan Allah Swt hingga seseorang akan lebih mudah untuk menghadapi kesulitan-kesulitan yang lebih besar (Rahman, 2006).

Hubungan yang dihasilkan antara kualitas zikir dengan kecemasan tergolong kuat. Dengan kata lain zikir yang berkualitas memberikan sumbangsih yang juat dan besar dalam mengatasi kecemasan dalam kehidupan. Ketika manusia mengalami kecemasan dalam menjalani kehidupan, maka manusia membutuhkan suatu kekuatan yang Maha Dahsyat 
Ability : Journal of Education and Social Analysis

Volume 2, Issue 4, Oktober 2021

Page : 63-76

diluar kemampuannya. Kekuatan tersebut diperoleh dengan berserah diri seutuhnya kepada Allah Swt dengan selalu berzikir (beribadah kepada-Nya). Karena pada dasarnya, manusia diciptkan Allah memiliki potensi untuk merasa cemas dan berkeluh kesah.

\section{Komunitas Tarekat Syattariyah di Kecamatan Medan Denai}

Komunitas Tarekat Syattariyah di kalangan masyarakat Minang yang merantau ke Kota Medan ada dua kelompok paham yang dianut yaitu, pertama, kaum tuo kedua, kaum mudo. Komunitas Tarekat Syattariyah di Medan tidak ditentukan jumlahnya, tetapi yang pasti para pengikut Syattariyah didominasi oleh para perantau dari Minang Kabau dan keberadaan para jamaah dan tuanku yang menjadi pemimpin ataupun amalan yang masih berjalan diantaranya Masjid Syekh Burhanuddin yang di jl. Rawa II gang Langgar Ujung, Masjid Syekh Burhanuddin di jl. Bakti gang Seto, Suray VII Koto jl. Bromo Lr. Tentram, dan Surau Tuanku Hasan Basry.

Keberadaan ajaran Tarekat Syattariyah di Kota Medan diterima dengan baik oleh masyarakat. Terbukti dengan banyaknya pengikut dari berbagai daerah di Kota Medan seperti Binjai, Stabat, dan Kisaran. Menurut Tuanku Hasan Basry, masyarakat Kota Medan sangat antusias dalam mengikuti pengajian-pengajian yang selalu diadakan di Surau Syekh Burhanuddin yang dikelola langsung oleh beliau. Mereka berbondong-bondong datang dari berbagai daerah untuk ikut berzikir dan kegiatan keagamaan lainnya. Tuanku Hasan Basry sendiri tidak tahu pasti berapa orang jamaah nya yang aktif dalam pengajian, karena beliau sendiri mempersilahkan siapa saja untuk ikut terjun kedalam ajaran Tarekat Syattariyah untuk sama-sama meningkatkan kualitas keimanan pada diri (Basry, 2021).

Dalam Tarekat Syattariyah ini, siapa saja boleh bergabung dalam komunitas untuk mengikuti kegiatan pengajian seperti zikir, bersholawat dan kegiatan keagamaan lainnya. Mereka yang ingin bergabung tidak perlu melakukan proses pendaftaran untuk menjadi jamaah. Menurut Tuanku Hasan Basry, adanya Tarekat Syattariyah ditengah-tengah masyarakat Medan ini sangat banyak manfaatnya, melihat situasi kota Medan yang dapat dikatakan sebagai kota metropolitan Tarekat Syattariyah datang untuk mengokohkan iman dan tingkat religius masyarakat. Terlebih lagi karena pandemi covid-19, banyak masyarakat yang terdampak sehingga mereka bisa saja putus asa dan menjadi jauh dari Allah. Oleh karena itu, Tarekat Syattariyah memberikan metode ketenangan melalui zikir sehingga mereka yang sedang dalam situasi kacau dapat lebih baik dan tetap mendekatkan diri kepada Allah Swt. 
Ability : Journal of Education and Social Analysis

Volume 2, Issue 4, Oktober 2021

Page : 63-76

Tarekat Syattariyah yang berkembang di Kecamatan Medan Denai melakukan segala aktivitas keagamaan di Mushollah Al-Izzah yang dikelola oleh Tuanku Hasan Basry. Meskipun letak lokasi musholla sangat terpencil dan masuk kedalam gang yang sempit, hal tersebut tidak menyurutkan para jamaah untuk datang ketika sedang ada pengajian. Dan meskipun lokasinya jauh dari jalan raya, mushollah Al-Izzah banyak dikenal masyarakat sebagai mushollah yang makmur karena selalu ramai jika ada kegiatan keagamaan dan banyak masyarakat sekitar yang melakukan shalat berjamaah di mushollah Al-Izzah. Tarekat Syattariyah menggunakan mazhab Syafi'i, dan ciri khas yang paling dominan adalah mereka menggunakan bahasa Arab saat khutbah di hari Jumat (Basry, 2021).

Kegiatan berzikir jamaah Tarekat Syattariyah dilakukan setelah shalat 5 waktu dengan nama zikir seribu, zikir seratus. Zikir seribu disesuaikan dengan kesanggupannya masing-masing dan rutinitas yang paling sering adalah setiap malam jumat melaksanakan zikir bersama di surau/mushollah Tuanku Hasan Basry di Jl. Bromo Gang Trimo dimulai pada jam 11.00 WIB, tetapi karena sedang pandemi zikir tersebut kadang tidak dijalankan.

Menurut penjelasan Tuanku Hasan Basry, semenja didirikannya surausurau Syekh Burhanuddin Tarekat Syattariyah di beberapa tempat Kota Medan, maka mulailah berdatangan para labai-labai dari Ulakan Pariaman. Kedatangan mereka ada yang memang sengaja dipanggil untuk menjadi pemimpin suatu surau dan ada yang datang dengan sukarela ke Medan. Menurut salah seorang jamaah Tarekat Syattariyah mengatakan bahwa ajaran dari Tarekat Syattariyah adalah ajaran yang fleksibel dalam menyikapi keberagamaan umat serta menyikapi tradisi budaya lokal (Maya, 2021).

\section{Pengaruh Zikir Terhadap Penurunan Kecemasan Terhadap Dampak Pandemi} Covid-19 Komunitas Tarekat Syattariyah di Kecamatan Medan Denai

Melihat perkembangan dari penyebaran virus corona (Covid-19) di Indonesia mengakibatkan meningkatnya kecemasan yang terdapat pada masyarakat. Adapun agama mengambil peran penting sebagai pegangan manusia di masa pandemi Covid-19.

Bagi jamaah Tarekat Syattariyah di Kecamatan Medan Denai yang juga terdampak pandemi Covid-19, pandemi ini adalah cara Allah Swt untuk menguji hamba-Nya dan ingin melihat apakah hamba-Nya tetap taat atau menjadi ingkar. Untuk menurunkan tingkat kecemasan, jamaah Tarekat Syattariyah melakukan kegiatan berzikir. Menurut mereka, dengan berzikir hati akan merasa lebih tenang dan tentram. 
Ability : Journal of Education and Social Analysis

Volume 2, Issue 4, Oktober 2021

Page : 63-76

Mencapai ketenangan batin bukanlah suatu hal yang mustahil, Allah Swt mengajarkan kita langkah nyata untuk mendapatkan ketenangan batin yaitu dengan selalu mengingat-Nya dan memuji nama-Nya (Syafi'i, 1985).

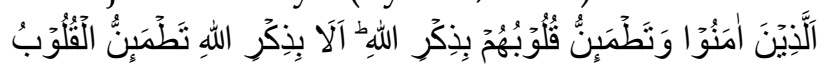

Artinya : (Yaitu) Orang-orang yang beriman dari hati mereka menjadi tenteram dengan mengingat Allah. Ingatlah, hanya dengan mengingat Allah hati menjadi tenteram. (Q.s Ar-Ra'd:28).

Dari ayat tersebut dapat dijelaskan bahwa zikir adalah sebuah metode yang bersumber langsung dari dari Allah Swt. Zikir disini diposisikan sebagai kehidupan yang mampu menenangkan gejolak kejiwaan yang dialami seseorang.

Zikir bila ditinjau dari segi bahasa (lughowi) adalah mengingat, sedangkan secara istilah adalah membasahi lidah dengan ucapan-ucapan pujian kepada Allah SWT. Zikir sendiri merupakan doa dimana akan mengingat dan mengungkapkan perasaan, kemauan dan keinginan. Sehingga zikir orang akan memperoleh ketenangan jiwa dan kelegaan batin, karena ia akan mengingat dirinya dan merasa diingatkan oleh Allah Swt (Saifullah, 2012). Zikir sendiri memiliki berbagai macam faedah, salah satunya adalah sebagai makanan hati dan ruh, membersihkan hati dan kotoran, menghadirkan ketenangan, dan selalu di bawah naungan Allah Swt.

Sumber lain mengatakan bahwa diriwayatkan dari Rasulullah, suatu Majelis Zikir memiliki keutamaan yaitu dikelilingi malaikat dan dirahmati oleh Allah, dihapus dosa-dosanya dan diganti dengan pahala, dan tidak akan pernah celaka atau dalam perlindungan Allah Swt. Dilihat dari pengertian ini, dapat dikatakan bahwa zikir dapat dijadikan sebuah metode alternatif yang baik untuk mendekatkan diri kepada Allah Swt dan memberikan ketenangan jiwa bagi siapapun yang sungguh-sungguh melakukannya. Sehingga, apabila zikir dijadikan sebuah metode alternatif dalam menangani sebuah permasalahan atau gangguan jiwa, seperti kecemasan, stres, depresi, maupun lainnya tentu hal ini merupakan jawaban terbaik (Saifullah, 2012).

Berdasarkan informasi yang peneliti dapatkan melalui wawancara dengan Tokoh Tarekat Syattariyah yaitu Tuanku Hasan Basry, Pengajian keagamaan seperti zikir dan sholawat dilakukan pada setiap malam Jumat. Namun, tidak dapat dipungkiri bahwa pandemi Covid-19 memberikan dampak bagi kegiatan keagamaan tersebut. Tuanku Hasan Basry mengatakan bahwa pada setiap malam Jumat dilakukan zikir bersama di Musholla Al-Izzah bersama dengan jamaah yang berdatangan dari berbagai daerah bahkan jamaah Tarekat Syattariyah melakukan perjalanan dakwah untuk mengisi tausiyah atau zikir bersama. Dalam satu malam jamaah Tarekat Syattariyah berkunjung ke tiga 
Ability : Journal of Education and Social Analysis

Volume 2, Issue 4, Oktober 2021

Page : 63-76

tempat untuk berdakwah. Namun, saat pandemi Covid-19 mereka tidak melakukan perjalanan dakwah kesuatu tempat dikarenakan Pemerintah juga membatasi aktivitas sosial dan membatasi kerumunan. Tuanku Hasan Basry juga mengatakan bahwa semenjak Covid-19 pengajian yang diadakan pada malam Jumat jamaah yang datang hanya sedikit. Namun jamaah Tarekat Syattariyah tetap melakukan zikir dari rumah sehingga kualitas iman mereka masih tetap terjaga.

Penurunan kecemasan pada jamaah Tarekat Syattariyah sangat signifikan, mereka yang berzikir merasakan sensasi ketenangan dan ketentraman dalam hati. Jamaah Tarekat Syattariyah menyerahkan segalanya kepada Allah Swt, apapun yang terjadi baik atau buruk tetap kembalikan kepada Allah Swt. Sehingga hati menjadi ikhlas menerima segala ujian dan cobaan termasuk pandemi Covid-19.

Untuk bertahan dari kejamnya Covid-19, jamaah Tarekat Syattariyah terus menerus mengokohkan pondasi zikir dalam hati mereka. Tuanku Hasan Basry mengatakan untuk tetap berzikir walau dimanapun, melakukan zikir hati karena zikir hati dapat dilakukan kapan saja dan dimana saja. Jadi, dengan begitu hati tetap diisi dengan kalimat-kalimat Allah.

Tuanku Hasan Basry mengatakan bahwa di masa pandemi Covid-19 kita harus selalu mengamalkan ibadah zikir disetiap kesempatan. Jangan membuang waktu untuk hal-hal yang membuat iman kita semakin menurun serta melakukan ibadah-ibadah lainnya yang dapat membuat kita semakin dekat dengan Allah Swt.

Tidak hanya jamaah Tarekat Syattariyah, masyarakat sekitar yang ikut dalam kegiatan berzikir juga merasakan ketenangan dari dalam hati. Mereka rutin melaukan zikir hati pada setiap harinya sehingga iman mereka tidak menurun dan imun dalam menghadapi pandemi Covid-19 ini menjadi semakin meningkat.

\section{KESIMPULAN}

Masalah yang terjadi di masa Pandemi Covid-19 ini berbagai macam, masalah ekonomi, pendidikan, kesehatan dan lain-lain. Dari masalah tersebut timbullah kecemasan dihati masyarakat, sehingga masyarakat menjadi takut dan menjadi kacau. Pada masalah ekonomi dan pendidikan, orangtua dituntut untuk tetap memberikan fasilitas pendidikan bagi anaknya tetapi disisi lain mereka tidak boleh bekerja lantas timbullah kecemasan jika mereka tidak dapat memenuhi kebutuhan hidup keluarganya.

Di masa pandemi Covid-19 ini masyarakat sangat emosional sehingga membuat mereka menjadi sensitif dan mudah marah. Hal tersebut sangat tidak 
Ability : Journal of Education and Social Analysis

Volume 2, Issue 4, Oktober 2021

Page : 63-76

bagus untuk ditampilkan ditengah-tengah masyarakat sehingga mereka perlu asupan dari dalam hati agar jiwa mereka menjadi lebih baik dan tenang. Zikir sangat memberikan efek yang luar biasa dalam ketenangan batin, siapa saja yang berzikir dengan tulus akan dapat merasakan manfaat dari zikir. Oleh karena itu, sebagaian besar masyarakat Kecamatan Medan Denai melakukan terapi zikir di rumah maupun di mushollah Tarekat Syattariyah.

Zikir terbukti memiliki kemampuan yang dapat menguatkan hati dari dalam dan dapat membuat seseorang menjadi semakin dekat dengan Allah. Zikir Tarekat Syattariyah sangat membantu dalam penurunan tingkat kecemasan bagi para jamaah Syattariyah khususnya dan masyarakat luas umumnya. Tuanku Hasan Basry mengatakan bahwa yang merasakan ketenangannya hanya yang mau terjun langsung untuk belajar Tarekat Syattariyah. Dan menurut peneliti, siapa saja bisa merasakan ketenangannya jika zikir dilakukan dengan ikhlas, tulus dan berharap ridha Allah Swt.

\section{REFERENCES}

Shihab, Quraish. 2008. Wawasan Alquran Tentang Zikir dan Do'a Cet III. Jakarta: Lentera Hati.

Hayat, Abdul. 2007. Bimbingan Konseling Qur'ani. Yogyakarta: Pustaka Pesantren.

Departemen Agama. 1989. Al-Qur'an dan terjemahnya. Bandung: Gema Risalah Press.

Najati. 2005. Al-qur'an dan Psikologi (Terjemahan). Jakarta: Aras Pustaka.

Adz-Dzakiey. Prophetic Intelligence; Kecerdasan Kenabian. Jakarta: Al Manar.

Anward. 2002. Dzikirullah: Suatu Trancendental being dan Terapi. Jurnal Indigenous.

Jalaluddin. 2009. Psikologi Agama (Edisi Revisi). Jakarta: PT Raja Grafindo Persada.

H. Miswar dkk. 2015. Akhlak Tasawuf Membangun Karakter Islami. Medan: Perdana Publishing.

Al Mahfani, M. Khalilurrahman. 2006. Keutamaan Doa dan Dzikir. Jakarta: Wahyu Media.

Hawari, Dadang. 1978. Al-Qur'an Ilmu Kedokteran Jiwa dan Kesehatan Jiwa. Jakarta: Gunung Agung.

Sutadi, Rusda Koto. 2010. Terapi Kognitif Untuk Depresi Dan Kecemasan. Semarang: IKIP Semarang Press.

Rahmadia, dkk. Dampak Virus Corona (Covid-19) Terhadap Ekonomi, Jurnal Ekonomi Islam. 
Ability : Journal of Education and Social Analysis

Volume 2, Issue 4, Oktober 2021

Page : 63-76

Kementerian Pendidikan dan Kebudayaan Republik Indonesia. Surat Edaran Mrndikbud tentang Pembelajaran secara Daring dan Bekerja dari Rumah dalam Rangka Pencegahan Penyebaran Corona Virus Disease (Covid-19).

Aulia. 2018. Memerangi Berita Bohong di Media Sosial (Studi Terhadap Gerakan Masyarakat Anti Fitnah Indonesia.

Luthfi, M. Mufid. Menelusuri Bagaimana Dampak Virus Corona (Covid-19) Bagi Perekonomian Indonesia.

Rahman, S. 2006. Kekayaan Hati Jadikan Hidup Lebih Bermakna. Yogyakarta: Ananda Publishing.

Syafi'i, Ahmad. Dzikir Sebagai Pembina Kesejahteraan Jiwa. Surabaya: Bina Ilmu.

Saifullah. 2012. Terapi Zikir Jama'ati di Desa Luwoo dan Tanggela Kabupaten Gorontalo. (Jurnal Al-Ulum).

Al-Jauzyah. 2002. Dzikir Cahaya Kehidupan. Jakarta: Gama Insani Press. 